\title{
1. Handbook of Culture and Migration: an introduction
}

\author{
Jeffrey H. Cohen and Ibrahim Sirkeci
}

Despite the debates and an ever expanding literature, migration remains an exceptional process that has long interested scholars (Spencer 2011: 6). Yet, despite ongoing debates and improved theories, much of the research on contemporary migration continues to echo Ravenstein's laws of migration (1889) and emphasise the economic logic of mobility. And while the economic foundation of migration and migration decision-making is a critical element if we are to understand human mobility, it is not the only or potentially the most important of drivers. There is a myriad of influences beyond jobs and wages as noted in the literature (e.g. De Jong and Graefe 2008; Fussell and Massey 2004).

Humans move for many reasons, and perhaps the most important point we make in this collection is also the most simple: culture (of migration) matters. The decisions that movers make are founded in culture and social practice and over time, patterns emerge in a population's sojourns. The patterns that come to characterise migration pathways are defined in the discussions that movers and potential movers have with their families and friends and determined by their access to resources as well as the securities and insecurities that are present at points of origin and destination (Cohen and Sirkeci 2011, 2016; Sirkeci 2009).

\section{THINKING ABOUT MOBILITY AND DEFINING A CULTURE OF MIGRATION}

Migration is an historical process, and while contemporary movement can seem extraordinary, the phenomenon is rooted in history and largely influenced by family and communities along with the contextual factors and the desires and wants of the individuals. In other words, migration isn't a solitary act or a singular decision about where a mover might just go. It is about the decisions that migrants, potential migrants and non-migrants make as members of households and in response to family and friends as well as the broader contexts in which those decisions are embedded. A household decision, migration is also a response to aspirations and opportunities, as well as community and resources - whether real or imagined. Migration is about perceived levels of security and insecurity which arise from and around conflicts, disagreements and discomforts that challenge movers and their families (Cohen and Sirkeci 2011; Sirkeci 2009).

Our definition of migration is founded upon the belief that the household is an adaptive unit in which social actors make decisions based upon their hopes and dreams, the aspirations of those around them as well as the resources that they manage, own and can access (Carling and Collins 2018; Cohen 2001; Wilk 1991). Quite plainly, migrants come to their decisions in discussions with the members of their households and with friends and relatives at points of origin and destination; and while there are times when a migrant will ignore her 


\section{Handbook of culture and migration}

or his household - or alternatively, times when the household will overwhelm a mover with demands - the household is always present. Resources, whether real or imagined, fixed or flexible, also foster outcomes as movers and their households manage wealth, education, experiences and connections (see for example Barglowski 2019; Cederberg and Villares-Varela 2019; Conway and Cohen 2002; Kofman 2018).

Mobility is a decision that reflects on security and perceptions in sending and destination communities (Cohen and Sirkeci 2011; Sirkeci 2009). It is clear that migrants leave their homes and their communities in search of work and economic security, but here we expand on the idea and argue that security is more than an economic outcome and driver. Security is a cultural response (as is insecurity), and often security and insecurity are organised in response to assumptions about wellbeing, aspirations and opportunities that can reach well beyond economic concerns to include things like education and personal freedom (see for example Cohen 2004; Gartaula et al. 2012; Okamoto and Wilkes 2008; Sirkeci 2006).

Migrants approach security as individuals and as members of households and communities. Migrants are social agents and their decisions to move are not made in a vacuum; rather they reflect on broader debates, material and non-material challenges (Icduygu et al. 1999) and physical as well as mental violence (van Kooy and Bowman 2019). Of course, migrants seek to live well, but it is critical that we understand the context of wellbeing and the challenges that movers - particularly from marginalised backgrounds - are trying to leave behind. Refugees face daily challenges to wellbeing; for them, insecurity can seem quite clear. Nevertheless, many refugees never leave their homelands, seeking to rebuild security rather than leave for parts unknown (Mzayek 2019).

There are many "kinds" of movers, the skilled mover, the unskilled migrant and the pilgrim and the refugee among others. These "kinds" of movers demand an asymmetry in both our theories and in our conceptualisation of power at points of origin and destination (and see Akileswaran and Lurie 2010; Green 2011; Luna and Rahman 2019; Wanzo 2020). The relationships we study between movers and stay-at-homes or refugees and the state can no longer be overlooked whether the outcomes are cultural, geographic, economic, or social.

In addition to understanding the ways in which power affects migration, contemporary theories look beyond the assumption that migrants followed direct pathways to new destinations where they settle and begin life anew and instead recognise the dynamic ways in which movers travel, following circular routes, relocating to meet new calculations and celebrating new opportunities (see Kearney 1996; Pries 2013; Schiller et al. 1992) as well as new identities (Lin 2020; Stephen 2017). And even as migrants organise and balance desires, demands, security and opportunity, they are sometimes challenged by conflicts and these can come in myriad forms. Disputes around belonging and citizenship are conflated with xenophobia and rising nationalism to complicate outcomes as well as opportunities.

While migration can look like the quick choice of an independent social actor, it is not. In fact, if migration was the choice of a person with little regard for their future, migrants would not succeed and mobility would be too messy to study. If however, as the research included in this volume argues, migration makes sense and follows specific patterns in response to inequalities, insecurities and cultural traditions, then we can make sense of it as a cultural process, an economic move, a political move, and a social event.

Understanding general facts, for example, that there were at least 272 million international migrants according to the $\mathrm{UN},{ }^{1}$ is a starting point from which we can explore macro-level trends. At the other end of the migration spectrum, a focus on movers (regardless of their 
motivations) emphasises choices and impacts of movement beyond the individual. We argue for a cultural approach that addresses the meso-level while embracing macro-level trends as well as the individual's needs and aspirations and taking into account how decisions are made as parts of households and communities (Faist 1997). While decisions matter, the desire to migrate is neither easy nor easily acted on. Migration is costly. Movers need social capital, human capital, financial capital and physical capability to set on migration (Sirkeci et al. 2019).

A complex phenomenon, we cannot define migration using only a single academic approach (and see Brettell and Hollifield 2014). To capture and understand the dynamic nature of human mobility demands we look across the social sciences and in this collection you will find the voices of anthropologists, geographers, sociologists, political scientists and more. Combined, the approaches represented by the researchers who have contributed their work capture the complexity of migration and why culture is critical to understanding.

We have organized the papers collected into four parts: Theory and Mobility; National Patterns; Tracing Mobilities in Space and Place; and Health and Mobility. Our goal is to capture the breadth of possibilities, anticipate some of the questions that drive research and model patterns that greet movers and non-movers, as well as the states they transit as they make their choices. In addition we are able to gain a sense of the dynamic ways that movers plan their sojourns, base their choices around real and perceived needs (and resources) and manage the concerns and aspirations of those around them. Offering a range of cases from across the globe while covering a variety of movers and myriad motivations, these contributions provide a realistic map of human mobility.

\section{NOTE}

1. https://www.un.org/en/development/desa/population/migration/data/estimates2/estimates19.asp.

\section{REFERENCES}

Akileswaran, C. and M. Lurie, 2010. Overcoming socioeconomic struggle and encountering risk: lived experiences of South African female migrants. NAPA Bulletin 34(1): 176-194.

Barglowski, K., 2019. Migrants' class and parenting: the role of cultural capital in migrants' inequalities in education. Journal of Ethnic and Migration Studies 45(11): 1970-1987.

Brettell, C. and J.F. Hollifield, editors, 2014. Anthropology and Migration: Talking Across Disciplines. New York: Routledge.

Carling, J. and F. Collins, 2018. Aspiration, desire and drivers of migration. Journal of Ethnic and Migration Studies 44(6): 909-926.

Cederberg, M. and M. Villares-Varela, 2019. Ethnic entrepreneurship and the question of agency: the role of different forms of capital, and the relevance of social class. Journal of Ethnic and Migration Studies 45(1): 115-132.

Cohen, J.H., 2001. Transnational migration in rural Oaxaca, Mexico: dependency, development and the household. American Anthropologist 103(4): 954-967.

Cohen, J.H., 2004. The Culture of Migration in Southern Mexico. Austin: University of Texas Press.

Cohen, J.H. and I. Sirkeci, 2011. Cultures of Migration: The Global Nature of Contemporary Mobility. Austin: University of Texas Press.

Cohen, J.H. and I. Sirkeci, 2016. Migration and insecurity: rethinking mobility in the neoliberal age. In J. Carrier (ed.), Anthropology after the Crisis. London: Routledge Publishing, pp. 96-113. 


\section{Handbook of culture and migration}

Conway, D. and J.H. Cohen, 2002. Local dynamics in multi-local, transnational spaces of rural Mexico: Oaxacan experiences. International Journal of Population Geography 9(1): 141-161.

De Jong, G.F. and D.R. Graefe, 2008. Immigrant redistribution and life course trigger events: evidence from US interstate migration. Migration Letters 5(2): 123-134.

Faist, T., 1997. The crucial meso-level. In T. Hammar, G. Brochmann, K. Tamas and T. Faist (eds), International Migration, Immobility and Development: Multidisciplinary Perspectives. New York: Berg, pp. 187-218

Fussell, E. and D.S. Massey, 2004. The limits to cumulative causation: international migration from Mexican urban areas. Demography 41(1): 151-171.

Gartaula, H., A. Niehof and L. Visser, 2012. Shifting perceptions of food security and land in the context of labour out-migration in rural Nepal. Food Security 4(2): 181-194.

Green, L. 2011. The nobodies: neoliberalism, violence, and migration. Medical Anthropology 30(4): 366-385.

Icduygu, A., D. Romano and I. Sirkeci, 1999. The ethnic question in an environment of insecurity: the Kurds in Turkey. Ethnic and Racial Studies 22(6): 991-1010.

Kearney, M., 1996. Reconceptualizing the Peasantry: Anthropology in Global Perspective. Boulder: Westview Press.

Kofman, E., 2018. Family migration as a class matter. International Migration 56(4): 33-46.

Lin, M., 2020. From alienated to activists: expressions and formation of group consciousness among Asian American young adults. Journal of Ethnic and Migration Studies 46(7): 1405-1424.

Luna, S.S. and M. Rahman, 2019. Migrant wives: dynamics of the empowerment process. Migration and Development 8(3): 320-337.

Mzayek, M., 2019. Understanding waiting and wellbeing through liminal experiences of Syrian refugees. Migration Letters 16(3): 369-377.

Okamoto, D.G. and R. Wilkes, 2008. The opportunities and costs of voice and exit: modelling ethnic group rebellion and emigration. Journal of Ethnic and Migration Studies 34(3): 347-369.

Pries, L., 2013. Ambiguities of global and transnational collective identities. GLOB Global Networks 13(1): 22-40.

Ravenstein, E.G., 1889. The laws of migration. Journal of the Royal Statistical Society 52(2): 241-301.

Schiller, N.G., L. Basch and C. Blanc-Szanton, 1992. Towards a definition of transnationalism: introductory remarks and research questions. In N.G. Schiller, L. Basch and C. Blanc-Szanton (eds), Toward a Transnational Perspective in Migration: Race, Class, Ethnicity, and Nationalism Reconsidered. New York: Annals of the New York Academy of Science, pp. ix-xiv.

Sirkeci, I., 2006. The environment of insecurity in Turkey and the emigration of Turkish Kurds to Germany. Lewiston: E. Mellen Press.

Sirkeci, I., 2009. Transnational mobility and conflict. Migration Letters 6(1): 3-14.

Sirkeci, I., D.E. Utku and M.M. Yüceşahin, 2019. Göç Çatışma Modelinin Katılım, Kalkınma ve Kitle Açıkları Üzerinden Bir Değerlendirmesi. Journal of Economy Culture and Society 59(1): 199-226.

Spencer, S., 2011. The Migration Debate. Bristol: Policy Press.

Stephen, L. 2017. Guatemalan immigration to Oregon: indigenous transborder communities. Oregon Historical Quarterly 118(4): 554-583.

van Kooy, J. and D. Bowman, 2019. "Surrounded with so much uncertainty": asylum seekers and manufactured precarity in Australia. Journal of Ethnic and Migration Studies 45(5): 693-710.

Wanzo, R., 2020. Migratory dissemblance. Signs: Journal of Women in Culture and Society 45(3): $547-553$.

Wilk, R.R., 1991. Household Ecology: Economic Change and Domestic Life Among the Kekchi Maya in Belize. Tucson: University of Arizona Press. 